\title{
Rosmarinic acid production in cell suspension cultures of Ehretia asperula Zollinger \& Moritz
}

\author{
Pham Thi My Tram ${ }^{1,2^{*}}$, Ngo Ke Suong ${ }^{3} \&$ Le Thi Thuy Tien ${ }^{1}$ \\ 1Department of Biotechnology, Ho Chi Minh University of Technology, Ho Chi Minh 700000, Vietnam \\ ${ }^{2}$ Institute of Applied Technology, Thu Dau Mot University, Binh Duong 820000, Vietnam \\ ${ }^{3}$ Institute of Tropical Biology, Vietnam Academy of Sciences and Technology, Ho Chi Minh 700000, Vietnam
}

*Email: 1680959@hcmut.edu.vn

OPEN ACCESS

\section{ARTICLE HISTORY}

Received: 17 September 2021

Accepted: 27 November 2021

Available online

Version 1.0:01 January 2022

\section{Check for updates}

\section{Additional information}

Peer review: Publisher thanks Sectional Editor and the other anonymous reviewers for their contribution to the peer review of this work.

Reprints \& permissions information is available at https://horizonepublishing.com/ journals/index.php/PST/open_access_policy

Publisher's Note: Horizon e-Publishing Group remains neutral with regard to jurisdictional claims in published maps and institutional affiliations.

Indexing: Plant Science Today, published by Horizon e-Publishing Group, is covered by Scopus, Web of Science, BIOSIS Previews, Clarivate Analytics, etc. See https:// horizonepublishing.com/journals/index.php/ PST/indexing_abstracting

Copyright: @ The Author(s). This is an openaccess article distributed under the terms of the Creative Commons Attribution License, which permits unrestricted use, distribution and reproduction in any medium, provided the original author and source are credited (https://creativecommons.org/licenses/ by/4.0/)

\section{CITE THIS ARTICLE}

Tram P T M, Suong N K, Le Thi Thuy Tien L T T $T$. Rosmarinic acid production in cell suspension cultures of Ehretia asperula Zollinger \& Moritz. Plant Science Today. 2022;9(1):70-75. https://doi.org/10.14719/pst.1490

\begin{abstract}
Plant cell cultures provide an alternative means for producing secondary compounds in food, cosmetic and pharmaceutical industries. Ehretia asperula Zollinger \& Moritzi is used as a traditional medicine for the treatment of liver detoxification, ulcers, tumors, inflammation and enhancing the body's resistance in Vietnam. The study was carried out to select suitable callus line for cell suspension cultures of E. asperula Zollinger \& Moritzi and investigate the effects of inoculum size, rotation speed and naphthalene acetic acid (NAA) on the proliferation of cell suspension cultures. In addition, the influence of light intensity on the growth and rosmarinic acid (RA) biosynthesis of cell suspension was also surveyed. After 4 weeks of culture, the white to pale yellow friable callus expanded significantly with a fresh weight (FW) of $0.788 \mathrm{~g}$ and a high RA content of $2.062 \mathrm{mg} / \mathrm{g} \mathrm{FW}$. An appropriate medium for cell proliferation was the liquid B5 medium, which contained $30 \mathrm{~g} / \mathrm{l}$ glucose, $0.1 \mathrm{mg} / \mathrm{l}$ benzyl adenine (BA) and $0.4 \mathrm{mg} / \mathrm{l} \mathrm{NAA}$. The results also demonstrated that a 1:20 ratio $(\mathrm{w} / \mathrm{v})$ inoculum size, darkness and rotation speed of $90 \mathrm{rpm}$ were the optimal conditions for the proliferation and RA accumulation to $188.217 \mathrm{mg} / \mathrm{l}$ in 4 weeks of culture. These findings showed that E. asperula Zollinger \& Moritzi cell suspension cultures could be a potential alternative approach for RA production in vitro.
\end{abstract}

\section{Keywords}

callus line, cell suspension cultures, Ehretia asperula, light intensity, rosmarinic acid, rotation speed

\section{Introduction}

Plant cell cultures may be a viable alternative for obtaining valuable secondary substances while avoiding the restrictions of traditional growing methods (1). The cultures in a bioreactor have been used to produce secondary metabolites in a variety of medicinal species, including paclitaxel in Taxus (2), shikonin in Lithospermum erythrorhizon (3), steroidal glycosides in Dioscorea deltoidea (4) and RA in Satureja khuzistanica (5).

Rosmarinic acid (RA) is a bioactive compound significantly found in the Boraginaceae and Lamiaceae families. RA, with a chemical formula of $\mathrm{C}_{18} \mathrm{H}_{16} \mathrm{O}_{8}$, is a polyphenol with many different biological activities such as anti-viral, anti-bacterial, anti-inflammatory, anti-oxidant, anti-carcinogenic and anti-depressant (6). Currently, RA is undergoing research and application in the field of food technology and medicine $(6,7)$.

Ehretia asperula Zollinger \& Moritzi (8) belongs to the Boraginaceae family, called "Xa Den" with the synonym Celastrus hindsii Benth. It often 
grows wildly in high mountains. In Vietnam, it is naturally inhabiting in forests and is commonly found in several Northern mountainous provinces, such as $\mathrm{Ha}$ Nam, Hoa Binh, Quang Ninh and Ninh Binh due to its great medicinal value (9). RA and lithospermic $B$ acid were the primary constituents in the extraction of leaves (10). In 2016, Ly reported that the total RA content in dried leaves of $E$. asperula was the highest when using extraction solvents of $50 \%$ methanol and $50 \%$ ethanol. However, methanol is toxic so it is only used in analysis, not in food and medicine, thus $50 \%$ ethanol was chosen (11). However, the research on cell suspension cultures from E. asperula to obtain bioactive compounds is still extremely limited.

The primary goal of this study was to select a suitable callus line for cell cultures. In addition, we examined some factors that influence on the proliferation of $E$. asperula cells in a liquid culture and bioactive compound accumulation.

\section{Materials and Methods}

E. asperula Zollinger \& Moritzi plants have been grown in the garden in Binh Duong province, provided by the Northern Nursery, Dong Hoi village, Dai Dinh commune, Tam Dao district, Vinh Phuc province. The plants of $E$. asperula were cultured in vitro at Experimental Research Center of Thu Dau Mot University, Vietnam. Their leaves were used as explants for callus cultures (Fig. 1).

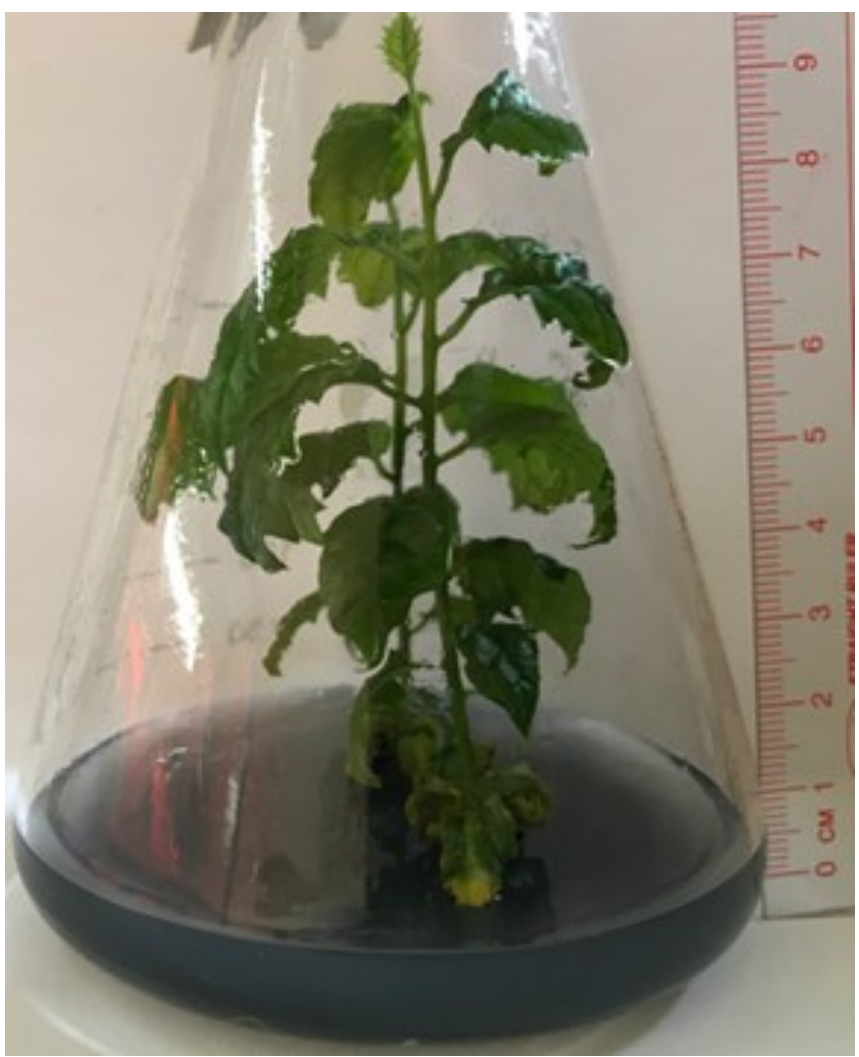

Fig. 1. In vitro regenerated plant of Ehretia asperula Zollinger \& Moritzi (12 weeks).

\section{Selection of a suitable callus line}

The explants from 12 week-old leaves that appeared dark green with approximate dimensions of $0.5 \times 1 \mathrm{~cm}^{2}$ were cut on the leaf surface. The medium used to promote callus formation included minerals and vitamin B5 (12), $100 \mathrm{mg} / \mathrm{l}$ inositol, $30 \mathrm{~g} / \mathrm{l}$ glucose, $7.5 \mathrm{~g} / \mathrm{l}$ agar, $0.5 \mathrm{~g} / \mathrm{l}$ activated coal, $0.4 \mathrm{mg} / \mathrm{l}$ 2,4-dichlorophenoxyacetic acid (2,4-D) and 0.1 $\mathrm{mg} / \mathrm{l} \mathrm{BA}$. The experiment was organized in complete darkness at $25 \pm 2{ }^{\circ} \mathrm{C}$. After 5 weeks, the callus was transferred to a new medium until it was friable. The color of the callus ranges from either white to yellowish or dark yellow to brown. These two types of callus were separated and subcultured to compare the proliferation and morphology.

Effects of inoculum size on the proliferation of $E$. asperula suspension cultures

The friable callus (15 weeks old) was transferred to liquid medium with different initial cell to medium ratios 1:10 to $1: 60(\mathrm{w} / \mathrm{v})$ and rotated at $150 \mathrm{rpm}$ on an orbital shaker in darkness. The medium composition was similar to that of callus culture. The proliferation of cell suspension cultures was evaluated by fresh cell weight after 4 weeks of culture.

Effects of rotation speed on the proliferation of E. asperula suspension cultures

The friable callus (15 weeks old) was transferred to liquid medium of the same composition with suitable inoculum size. The cultures were constantly rotated at various speeds $(60,90,120$ and $150 \mathrm{rpm})$ in the darkness. The proliferation of cell suspension cultures was evaluated by fresh cell weight after 4 weeks of culture.

\section{Effects of NAA on the proliferation of E. asperula cell sus- pension cultures}

In this study, the optimal culture conditions from two previous experiments were applied. The friable callus (15 weeks old) was transferred to liquid medium supplemented with NAA (0.2 - $1 \mathrm{mg} / \mathrm{l})$ which substituted for 2,4-D. The proliferation of cell suspension cultures was evaluated by fresh cell weight after 4 weeks of culture.

Effects of light intensity on RA yield of E. asperula cell suspension cultures

The cell suspension cultures of E. asperula were exposed to three different light intensities. The cultures were either kept entirely dark or exposed to continuous light (2000 lux and 4000 lux). After 7 days of culture, the fresh cell weight was used to assess the proliferation of cell suspension cultures. Fresh cell biomass and a post-centrifugation liquid medium were used to determine RA content.

\section{Morphology observation}

Cells were stained with lugol $1 \%$ for structural assessment of the cells and starch granules under an optical microscope.

\section{Growth measurement}

The proliferation of $E$. asperula was measured on fresh weight of cell as well as the color of cell inoculum and liquid medium. $10 \mathrm{ml}$ of the cell suspension was centrifuged in a $15 \mathrm{ml}$ tube for $20 \mathrm{~min}$ at $5500 \mathrm{rpm}$ to separate the biomass and liquid medium.

\section{Determination of RA content}

The fresh biomass of suspension cells harvested after 7,14 , 21, 28 and 35 days of culture was soaked for 3 hrs with a 
$50 \%$ ethanol solvent at the rate of $1: 12(\mathrm{w} / \mathrm{v})$, then sealed and placed on a magnetic stirrer at $200 \mathrm{rpm}$. The extract was passed through filter paper retaining the clear solution to analyze RA content as described (11).

RA content was deliberated based on a complex bright yellow reaction between RA and Zirconium (IV) oxide chloride, with an adsorption at the wavelength of $362 \mathrm{~nm}$ on a spectrophotometer (13). The concentration of RA was calculated based on a graph with RA (Sigma-Aldrich) at the

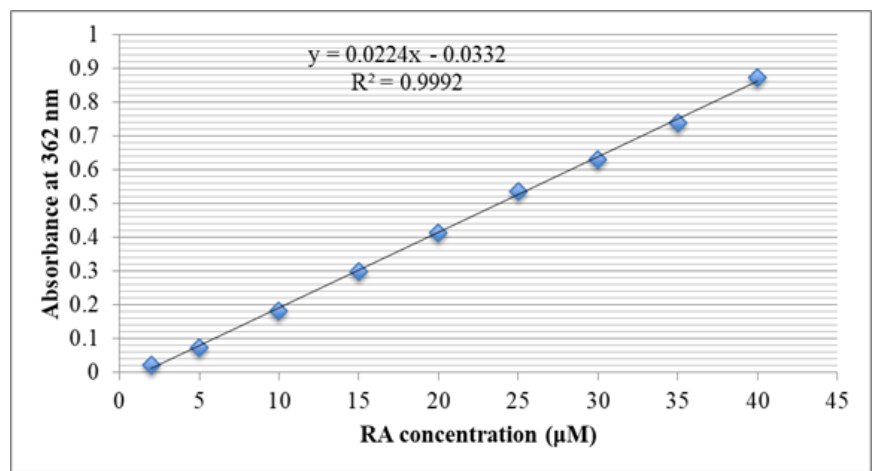

Fig. 2. The standard calibration curve of RA at $362 \mathrm{~nm}$.

concentration range of 2 - $40 \mu \mathrm{M}$ (Fig. 2).

\section{Statistical method}

Data was expressed as the mean \pm SD of 3 replicates, statistically processed using Statgraphics Centurion XV software with a significant difference of $5 \%$.

\section{Results and Discussion}

\section{Selection of a suitable callus line}

After the second subcultures, 15 week old callus with varying colors ranging from white to brown appeared. To select a suitable callus line for cell suspension cultures, white to pale yellow callus (W) and dark yellow to brown callus $(\mathrm{Y})$ were separated for further monitoring of cell proliferation.

After 4 weeks, the $\mathrm{W}$ showed a significant increase in biomass and the color of the callus turned to pale yellow. For the $\mathrm{Y}$, the biomass increased slightly with brown or black coloration. This may be most likely due to excessive phenol release in the cell, which inhibits cell proliferation and causes cell death (Fig. 3, Table 1).
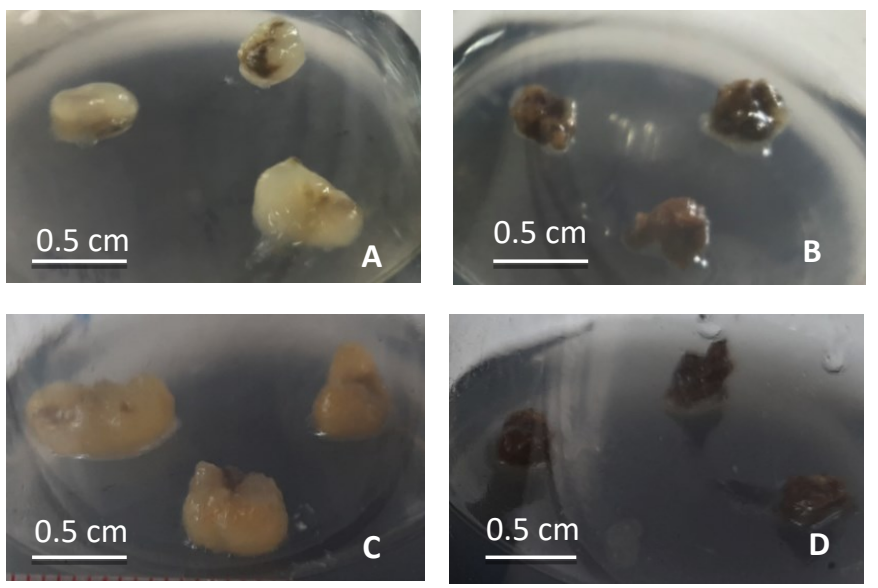

Fig. 3. A. White to pale yellow callus at first day; B. Dark yellow to brown callus at first day; $C$. White to pale yellow callus after 4 weeks; D. Dark yellow to brown callus after 4 weeks.
Table 1. Effects of cell line on callus proliferation in E. asperula Zollinger \& Moritzi after 4 weeks

\begin{tabular}{cccc}
\hline \multirow{2}{*}{ Callus line } & \multicolumn{2}{c}{ Fresh weight $(\mathbf{g})$} & \multirow{2}{*}{ RA content $(\mathbf{m g} / \mathbf{g ~ F W})$} \\
\cline { 2 - 3 } & Initial & After 4 weeks & \\
\hline W & 0.05 & $0.089^{\mathrm{a}} \pm 0.021$ & $2.062^{\mathrm{a}} \pm 0.047$ \\
Y & 0.05 & $0.052^{\mathrm{b}} \pm 0.002$ & $0.793^{\mathrm{b}} \pm 0.005$ \\
\hline
\end{tabular}

Values with different letters indicate a significant difference at the $5 \%$ level according to LSD test.

Morphologically, $\mathrm{W}$ and $\mathrm{Y}$ cells were similar in that they were both elongated and contained a large number of starch granules. However, $W$ cells have more starch granules than $Y$ cells, as shown by the lugol coloration under the optical microscope in Fig. 4. The ideal callus cells to initiate cell suspension cultures are those that have a large nucleus and concentrated cytoplasm (14). The presence of starch was needed for cell division. Cells with slow proliferation

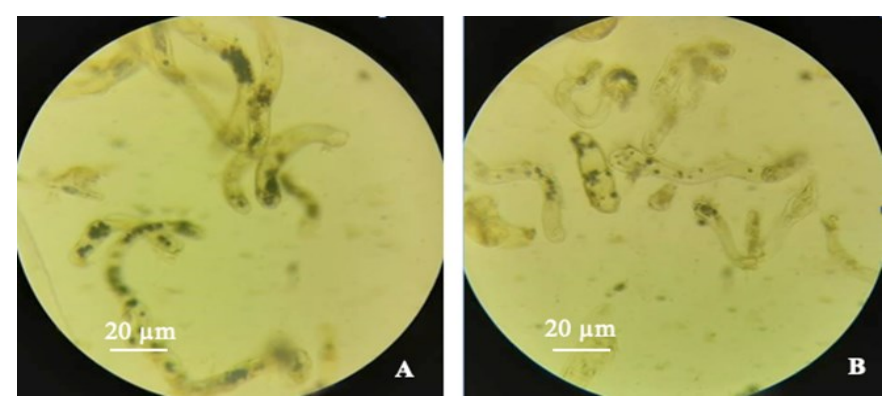

Fig. 4. A. Cells of white to pale yellow callus; B. Cells of dark yellow to brown callus under the optical microscope (400x magnification).

are not suitable for establishing culture systems (14).

The RA concentration of the W was $2.062 \mathrm{mg} / \mathrm{g}$ FW, which is much higher than the RA concentration of the $Y$ $(0.793 \mathrm{mg} / \mathrm{g} F W)$. Thus, in this study, the white to light yellow callus was the best as raw material for cell suspension cultures of $E$. asperula.

The W (Fig. 5.A) was transferred into liquid medium to create cell suspensions. After 4 weeks of culture, the cell suspension became dark yellow, consisting of single cells and small clusters (Fig. 5.B-C).
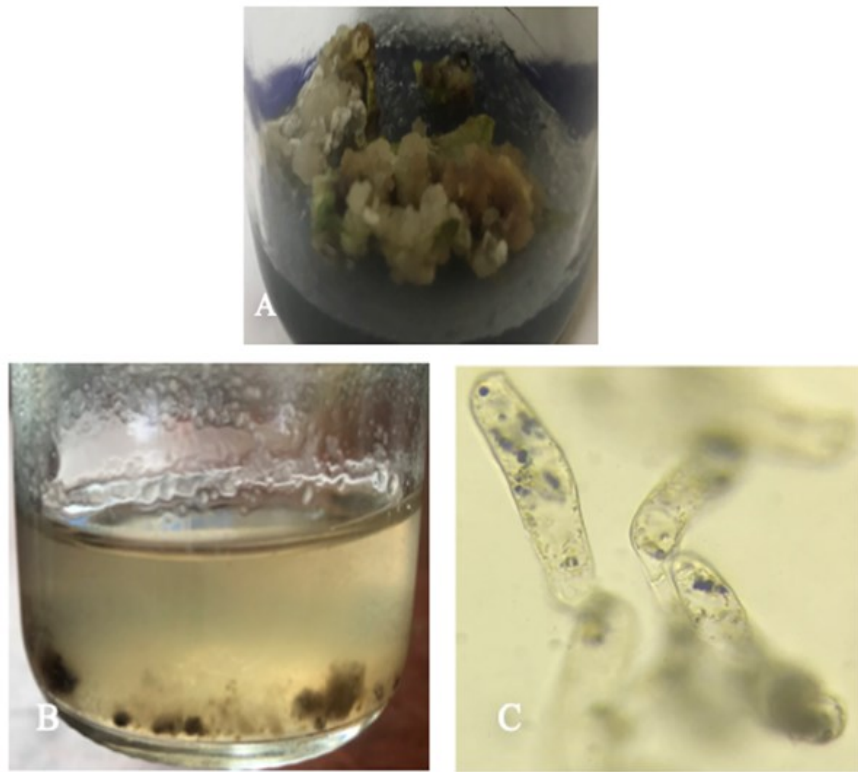

Fig. 5. A. Friable callus; B. Cell suspension after 4 weeks; C. Cell suspension under the optical microscope (400x magnification). 
Effects of inoculum size on the proliferation of E. asperula cell suspension cultures

The initial cell density in the culture medium markedly in-

Table 2. Effects of inoculum size on the proliferation of E. asperula Zollinger \& Moritzi cell suspension cultures after 4 weeks

\begin{tabular}{cccc}
\hline \multirow{2}{*}{$\begin{array}{c}\text { Inoculum size } \\
(\mathbf{w} / \mathbf{v})\end{array}$} & \multicolumn{2}{c}{ Fresh weight $(\mathbf{g} / \mathbf{L})$} & Fresh weight increased \\
\cline { 2 - 3 } & Initial & After 4 weeks & (g) \\
\hline $1: 10$ & 100 & $166.867 \pm 5.053$ & $66.867 \pm 5.053^{\mathrm{b}}$ \\
$1: 20$ & 50 & $134.400 \pm 10.944$ & $84.400 \pm 10.944^{\mathrm{a}}$ \\
$1: 30$ & 33.333 & $114.167 \pm 4.976$ & $80.834 \pm 4.976^{\mathrm{a}}$ \\
$1: 40$ & 25 & $85.522 \pm 2.455$ & $60.522 \pm 2.455^{\mathrm{b}}$ \\
$1: 50$ & 20 & $67.492 \pm 7.767$ & $47.492 \pm 7.767^{\mathrm{c}}$ \\
$1: 60$ & 16.667 & $59.567 \pm 1.026$ & $42.899 \pm 1.026^{\mathrm{c}}$ \\
\hline
\end{tabular}

Values with different letters indicate a significant difference at the $5 \%$ level according to LSD test

fluenced the growth of the cell suspension (15). The cell biomass increased after 4 weeks of culture in all treatments (Table 2) and the cell suspension proliferated best at the inoculum size of 1:20 (w/v). Cell biomass tended to decrease gradually as the inoculum size varied from 1:30 to 1:60 (w/v). This could be owing to a lack of cell-to-cell interaction, which inhibited cell division. On the other hand, high inoculum size can lower the growth rate and biomass yield $(15,16)$. In this study, the biomass of the cell suspension reduced at a 1:10 (w/v) inoculum size because of the competition for nutrients as well as oxygen content in the medium.

It was showed that cell density affected the growth of strawberry cell suspension (Fragaria ananassa L.), with a 1:20 (w/v) inoculum size being the most effective (17). However, unlike for Panax ginseng suspension cultures, cell growth was low at an inoculum size of 1:25 (w/v) and maximum cell growth was achieved with increasing inoculum size up to $1: 10(\mathrm{w} / \mathrm{v})$. The maximum saponin yield was achieved at a 1:16.67 (w/v) inoculum size (18).

This suggests that plant cells require a crucial minimum inoculum density for effective cell growth and secondary metabolite production (16). As a result, a 1:20 inoculum size is ideal for E. asperula cell suspension multiplication.

Effects of rotation speed on the proliferation of E. asperula cell suspension cultures

The rotation speed is a critical factor in the creation of plant cell suspension cultures. Plant cells mixed in liquid medium will allow for consistent nutrient uptake and a sufficient supply of $\mathrm{O}_{2}$ and $\mathrm{CO}_{2}$. However, rotation and aeration can exert hydrodynamic stress on cells due to the physical characteristics of suspended cells. Shear pressures cause many changes in aggregate size, shape, cell integrity, viability and ultimately, biomass accumulation and secondary metabolism in cells (19).

The effects of rotation speed on the proliferation of E. asperula cell suspension was shown in Table 3 . The maximum fresh cell weight $(146.844 \mathrm{~g} / \mathrm{l})$ was observed at $90 \mathrm{rpm}$. At higher speed (120 and $150 \mathrm{rpm}$ ), cell biomass increased more slowly, with some cells sticking to the flask, thereby
Table 3. Effects of rotation speed on the proliferation of $E$. asperula Zollinger $\&$ Moritzi cell suspension cultures after 4 weeks

\begin{tabular}{cc}
\hline Rotation speed $(\mathbf{r p m})$ & Fresh weight $(\mathbf{g} / \mathbf{L})$ \\
\hline 60 & $73.356 \pm 4.317^{\mathrm{a}}$ \\
90 & $146.844 \pm 12.627^{\mathrm{c}}$ \\
120 & $128.400 \pm 7.711^{\mathrm{b}}$ \\
150 & $121.111 \pm 3.466^{\mathrm{b}}$ \\
\hline
\end{tabular}

Values with different letters indicate a significant difference at the $5 \%$ level according to LSD test

reducing their exposure to the nutrient medium. At $60 \mathrm{rpm}$, the cell suspension grew slowly with a fresh cell weight of $73.356 \mathrm{~g} / \mathrm{l}$. Similarly, in Zingiber zerumbet Smith cell suspension cultures, the rotation speeds of 70 and $100 \mathrm{rpm}$ supported the cell growth, with $70 \mathrm{rpm}$ being preferred. At $40 \mathrm{rpm}$, the cells proliferated slowly (20). In contrast, in Spilanthes acmella Murr. cell suspension cultures, the cells grew best at $120 \mathrm{rpm}$. At higher speeds (150 and 180), several cells died due to hydraulic stress. At 60 and $90 \mathrm{rpm}$, the cells also decreased viability due to clustering (19).

Effects of NAA on the proliferation of E. asperula cell suspension cultures

In the present study, to determine the optimum level of plant growth regulators in E. asperula different concentrations of NAA ( $\mathrm{mg} / \mathrm{l})$ were used in the liquid B5 medium for cell suspension growth.

As shown in Table 4, the cell proliferation was slow with $0.2 \mathrm{mg} / \mathrm{l}$ NAA or without growth regulators. The higher cell biomass was observed in media supplemented with 0.4 - $1 \mathrm{mg} / \mathrm{l}$ NAA. Therein, the highest fresh weight (136.089 g/l)

Table 4. Effects of NAA on the proliferation of E. asperula Zollinger \& Moritzi cell suspension cultures after 4 weeks

\begin{tabular}{cc}
\hline NAA $(\mathbf{m g} / \mathbf{L})$ & Fresh weight $(\mathbf{g} / \mathbf{L})$ \\
\hline 0 & $103.389 \pm 7.934^{\mathrm{a}}$ \\
0.2 & $109.100 \pm 3.509^{\mathrm{ab}}$ \\
0.4 & $127.533 \pm 8.690^{\mathrm{c}}$ \\
0.6 & $134.933 \pm 4.284^{\mathrm{c}}$ \\
0.8 & $121.389 \pm 9.581^{\mathrm{c}}$ \\
1 & $136.089 \pm 13.580^{\mathrm{c}}$ \\
Control (0.4 mg/L 2,4-D) & $122.456 \pm 8.556^{\mathrm{bc}}$
\end{tabular}

Values with different letters indicate a significant difference at the $5 \%$ level according to LSD test.

was observed in $1 \mathrm{mg} / \mathrm{l}$ NAA treatment. However, the statistical data did not show any difference between treatments supplemented with NAA from 0.4 to $1 \mathrm{mg} / \mathrm{l}$ or $0.4 \mathrm{mg} / \mathrm{l} 2,4-\mathrm{D}$ (control) (Table 4). 2,4-D is the commonly used auxin to induce the formation and proliferation of callus, followed by NAA and picloram. NAA appears to support the growth of cell suspension rather than the growth of callus (21). At a high concentration, 2,4-D may lead to suppression of the nucleic acid's normal function and protein biosynthesis, which causes cells to turn brown and reduce viability (22).

Similarly, in Curcuma mangga cell cultures, MS medium supplemented with $1 \mathrm{mg} / \mathrm{l}$ 2,4-D was suitable for callus formation that was was friable and white colored. However, the cell suspension became brown after 3 subcultures 
using 2,4-D. Therefore, the concentration of 2,4-D was reduced to $0.3 \mathrm{mg} / \mathrm{l}$ and $0.1 \mathrm{mg} / \mathrm{l}$ NAA was added as an antioxidant to limit browning during the growth of the cell suspension (14).

Based on the analytics, the liquid B5 medium supplemented with $0.1 \mathrm{mg} / \mathrm{l} \mathrm{BA}$ and $0.4 \mathrm{mg} / \mathrm{l} \mathrm{NAA}$ was selected as the suitable medium for the cell suspension growth.

Effects of light intensity on RA yield of E. asperula cell suspension cultures

The light spectrum, intensity and duration of illumination also significantly affect plant cell cultures (23).

As shown in Fig. 6, at 4000 lux, the cell biomass increased faster than the other two treatments, which suggests that high light intensity plays a role in promoting cell division during the growth phase from week 1 to week 3 . By week 4 , the cell suspension had gone into a steady growth phase and the cell weight was elevated in all treatments. In

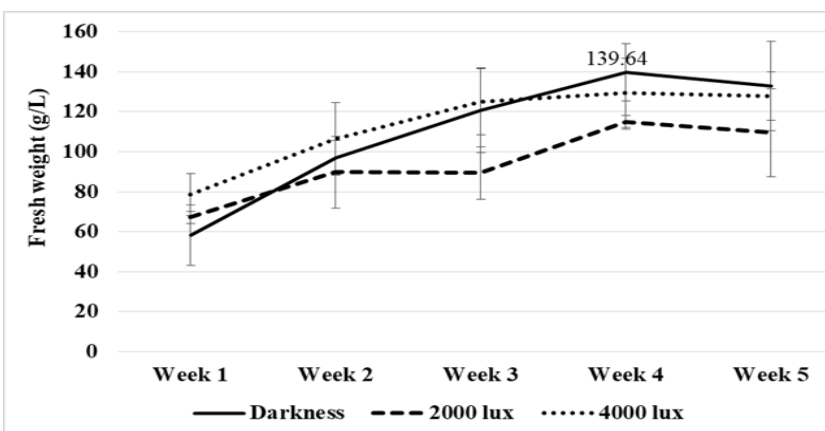

Fig. 6. Effects of light intensity on the proliferation of $E$. asperula Zollinger \& Moritzi cell suspension cultures.

particular, in total darkness, the cell proliferation was better with a fresh cell weight of $139.64 \mathrm{~g} / \mathrm{l}$. The cell biomass decreased in all treatments after 5 weeks.

Table 5 demonstrated that, in the darkness, RA concentration increased gradually from week 1 to week 4 to the increase of biomass. RA yield reached the highest
Similarly, in cell suspension cultures of Ocimum sanctus L. It was showed that RA biosynthesis was associated with cell proliferation with the highest concentration of RA reaching $104 \mathrm{mg} / \mathrm{l}$ while the cells were cultured in MS medium supplemented with $1 \mathrm{mg} / \mathrm{l}$ 2,4-D and $0.1 \mathrm{mg} / \mathrm{l} \mathrm{Kinetin} \mathrm{(24).}$

The results showed that RA was secreted into liquid medium at a significant rate. It was reported that in Centella asiatica $\mathrm{L}$. Urban, flavonoid content was detected in both suspended cells and in culture media with higher intracellular concentrations (21).

Light is crucial for photosynthesis, but depending on the intensity, it can also harm plants. Low light intensity cause cells to grow poorly, but higher intensity that stimulate photo-oxidation result in inhibited biomass production, especially when combined with other environmental factors (25). In general, the growth and production of secondary compounds of plant cell cultures are affected by internal factors, including genotype, plant growth regulators and external factors such as light, temperature and humidity.

\section{Conclusion}

In conclusion, for the first time, we effectively generated callus and cell suspension cultures of $E$. asperula Zollinger \& Moritzi for RA production. Good callus was the white to light yellow friable callus. The cell suspension grew well and produced the most RA in the liquid B5 medium with 30 $\mathrm{g} / \mathrm{l}$ glucose, $0.4 \mathrm{mg} / \mathrm{l} \mathrm{NAA}, 0.1 \mathrm{mg} / \mathrm{l} \mathrm{BA}$ on an orbital shaker at $90 \mathrm{rpm}$ in darkness. The highest cell biomass and RA concentration reached $139.64 \mathrm{~g} / \mathrm{l}$ and $188.217 \mathrm{mg} / \mathrm{l}$ after 4 weeks of culture. Further, commercially oriented study is needed to investigate the potential of E. asperula Zollinger \& Moritzi for improved RA synthesis by elicitation, precursor feeding and metabolic engineering, which could be useful for secondary metabolite research and development.

Table 5. Effects of light intensity on RA yield of E. asperula Zollinger \& Moritzi cell suspension cultures

\begin{tabular}{|c|c|c|c|c|}
\hline \multirow{2}{*}{ Week } & \multirow{2}{*}{ Light intensity } & \multicolumn{3}{|c|}{ RA yield (mg/L) } \\
\hline & & In biomass & In liquid medium & Total \\
\hline & Darkness & $28.353 \pm 0.859^{\mathrm{a}}$ & $49.768 \pm 1.675^{a}$ & $78.121 \pm 1.372^{\mathrm{a}}$ \\
\hline \multirow[t]{3}{*}{1} & $2000 \operatorname{lux}$ & $33.076 \pm 0.496^{b}$ & $57.010 \pm 0.465^{\mathrm{cd}}$ & $90.086 \pm 0.948^{b}$ \\
\hline & 4000 lux & $49.210 \pm 2.321^{\mathrm{e}}$ & $58.351 \pm 1.229^{\mathrm{de}}$ & $107.829 \pm 3.123^{\text {de }}$ \\
\hline & Darkness & $44.071 \pm 1.404^{\mathrm{cd}}$ & $48.963 \pm 0.465^{a}$ & $93.035 \pm 1.821^{\mathrm{bc}}$ \\
\hline \multirow[t]{2}{*}{2} & $2000 \operatorname{lux}$ & $48.895 \pm 0.500^{e}$ & $47.086 \pm 1.229^{\mathrm{a}}$ & $95.981 \pm 1.236^{c}$ \\
\hline & 4000 lux & $54.774 \pm 0.297^{f}$ & $53.791 \pm 1.675^{b}$ & $108.566 \pm 1.485^{\mathrm{e}}$ \\
\hline \multirow[t]{3}{*}{3} & 2000 lux & $39.901 \pm 1.085^{c}$ & $54.596 \pm 0.465^{b c}$ & $94.497 \pm 0.684^{b c}$ \\
\hline & $4000 \operatorname{lux}$ & $48.601 \pm 1.94^{e}$ & $62.642 \pm 0.465^{f}$ & $111.243 \pm 2.261^{\mathrm{ef}}$ \\
\hline & Darkness & $94.731 \pm 9.178^{k}$ & $93.486 \pm 2.414^{k}$ & $188.217 \pm 6.910^{k}$ \\
\hline \multirow[t]{3}{*}{4} & 2000 lux & $46.625 \pm 2.215^{\mathrm{de}}$ & $61.033 \pm 4.575 \mathrm{e}^{f}$ & $107.658 \pm 6.333^{\mathrm{de}}$ \\
\hline & $4000 \operatorname{lux}$ & $47.343 \pm 1.907^{\mathrm{de}}$ & $68.274 \pm 2.025^{\mathrm{g}}$ & $115.617 \pm 2.462^{f}$ \\
\hline & Darkness & $84.728 \pm 0.641^{i}$ & 89. $31 \pm 1.229^{i}$ & $174.459 \pm 0.612^{\mathrm{i}}$ \\
\hline 5 & 2000 lux & $59.299 \pm 0.529^{g}$ & $69.079 \pm 1.229 \mathrm{~g}$ & $128.378 \pm 1.488^{\mathrm{g}}$ \\
\hline
\end{tabular}

$(188.217 \mathrm{mg} / \mathrm{l})$ after 4 weeks. Thereafter, it decreased with the cell biomass at week 5. At 2000 lux, RA levels increased steadily from week 1 to week 5 exhibiting $128.378 \mathrm{mg} / \mathrm{l}$. At 4000 lux, RA concentration increased from week 1 to week 4 and decreased at week 5 .

\section{Acknowledgements}

We acknowledge the support of time and facilities from Ho Chi Minh City University of Technology (HCMUT), VNU-HCM and Thu Dau Mot University, Vietnam for this study. 


\section{Authors contributions}

Pham Thi My Tram has done plant tissue cultures, extraction of RA, spectrophotometric analysis, guided and supervised by Assoc. Prof. Le Thi Thuy Tien and Dr. Sci, Assoc. Prof. Ngo Ke Suong.

\section{Compliance with ethical standards}

Conflict of interest: Authors declare no conflict of interest .

\section{Ethical issues: None.}

\section{References}

1. Chandran H, Meena M, Barupal T, Sharma K. Plant tissue culture as a perpetual source for production of industrially important bioactive compounds. Biotechnol Rep. 2020;26: e00450. https:// doi.org/10.1016/j.btre.2020.e00450

2. Li YC, Tao WY, Cheng L. Paclitaxel production using co-culture of Taxus suspension cells and paclitaxel-producing endophytic fungi in a co-bioreactor. Appl Microbiol Biotechnol. 2009;83(2):233-39. https://doi.org/10.1007/s00253-009-1856-4

3. Yazaki K. Lithospermum erythrorhizon cell cultures: Present and future aspects. Plant Biotechnol. 2017;34(3):131-42. https:// doi.org/10.5511/plantbiotechnology.17.0823a

4. Titova MV, Popova EV, Konstantinova SV, Kochkin DV, Ivanov IM, Klyushin AG, Titova EV, Nebera EA, Vasilevskaya ER, Tolmacheva GS, Kotenkova EA, Nosov AM, Paek KY. Suspension cell culture of Dioscorea deltoidea-A renewable source of biomass and furostanol glycosides for food and pharmaceutical industry. Agronomy. 2021;11(2):394. https://doi.org/10.3390/agronomy11020394

5. Khojasteh A, Mirjalili MH, Palazon J, Eibl R, Cusido RM. Methyl jasmonate enhanced production of rosmarinic acid in cell cultures of Satureja khuzistanica in a bioreactor. Eng Life Sci. 2016;16(8):74049. https://doi.org/10.1002/elsc.201600064

6. Bhatt R, Mishra N, Bansal PK. Phytochemical, pharmacological and pharmacokinetics effects of rosmarinic acid. J Pharm Sci Innov. 2013;2(2):28-34. https://doi.org/10.7897/2277-4572.02215

7. Nadeem M, Imran M, Gondal TA, Imran A, Shahbaz M, Amir RM, Sajid MW, Qaisrani TB, Atif M, Hussain G, Salehi B, Ostrander EA, Martorell M, Sharifi-Rad J, Cho WC, Martins N. Therapeutic potential of rosmarinic acid: A comprehensive review. Appl Sci. 2019;9(15):3139. https://doi.org/10.3390/app9153139

8. Hoa HQ, Khanh TC. Botanical characteristics of three medicinal plants belonging to the Ehretia genus, in the Boraginaceae family. Journal of Medicinal Materials. 2009;14(3):137-41 [In Vietnamese]. Available from: http://vienduoclieu.org.vn/tap-chi/dac-diem-thucvat-cua-ba-loai-cay-thuoc-thuoc-chi-cuom-rung-ehretia-p-br-ho-voi -voi-boraginaceae-tap-chi-duoc-lieu-tap-14-so-3-2009-1196_2090

9. Viet TD, Xuan TD, Van TM, Andriana Y, Rayee R, Tran HD. Comprehensive fractionation of antioxidants and GC-MS and ESI-MS fingerprints of Celastrus hindsii leaves. Medicines. 2019;6(2):64. https:// doi.org/10.3390/medicines6020064

10. Ly TN, Shimoyamada M, Yamauchi R. Isolation and characterization of rosmarinic acid oligomers in Celastrus hindsii Benth. leaves and their antioxidative activity. J Agric Food Chem. 2006;54(11):3786-93. https://doi.org/10.1021/jf052743f

11. Ly TN. Separation process of rosmarinic acid and their derivatives from Celastrus hindsii Benth. leaves. VJST. 2016;54(2C):380-87. https://doi.org/10.15625/2525-2518/54/2C/11865

12. Gamborg OL, Miller RA, Ojima K. Nutrient requirements of suspension cultures of soybean root cells. Exp. Cell Res. 1968;50:151-58. https://doi.org/10.1016/0014-4827(68)90403-5
13. Öztürk M, Duru ME, İnce B, Harmandar M, Topçu G. A new rapid spectrophotometric method to determine the rosmarinic acid level in plant extracts. Food Chem. 2010;123(4):1352-56. https:// doi.org/10.1016/j.foodchem.2010.06.021

14. Sundram TC, Annuar MSM, Khalid N. Optimization of culture condition for callus induction from shoot buds for establishment of rapid growing cell suspension cultures of mango ginger (Curcuma mangga). Aust J Crop Sci. 2012;6(7): 1139-46. Available from: http:// www.cropj.com/sundram_6_7_2012_1139_1146.pdf

15. Haida Z, Syahida A, Ariff SM, Maziah M, Hakiman M. Factors affecting cell biomass and flavonoid production of Ficus deltoidea var. kunstleri in cell suspension culture system. Sci Rep. 2019;9(1):9533. https://doi.org/10.1038/s41598-019-46042-w

16. Saad NC, Mazlan FI, Karim KA. Factors affecting the establishment and growth of Pogostemon cablin cell suspension cultures. IJARSET. 2016;3(10):2790-96. Available from: http://www.ijarset.com/ upload/2016/october/9_IJARSET_khiriah.pdf

17. Tram PTM, Tien LTT. Studing on growth of strawberry (Fragaria ananassa L.) cell suspension cultures for anthocyanin production. STDJ. 2012;15(2):69-77. https://doi.org/10.32508/stdj.v15i2.1802

18. Thanh NT, Murthy HN, Yu KW, Jeong CS, Hahn EJ, Paek KY. Effect of inoculum size on biomass accumulation and ginsenoside production by large-scale cell suspension cultures of Panax ginseng. J Plant Biotechnol. 2004;6(4):265-68. Available from: https:// www.koreascience.or.kr/article/JAKO200420828098816.kr

19. Singh M, Chaturvedi R. Evaluation of nutrient uptake and physical parameters on cell biomass growth and production of spilanthol in suspension cultures of Spilanthes acmella Murr. Bioprocess Biosyst Eng. 2012;35(6):943-51. https://doi.org/10.1007/s00449-012-0679-3

20. Jalil M, Annuar MSM, Tan BC, Khalid N. Effects of selected physicochemical parameters on zerumbone production of Zingiber zerumbet Smith cell suspension culture. eCAM. 2015:1-7. https:// doi.org/10.1155/2015/757514

21. Tan S, Radzali M, Arbakariya A, Mahmood M. Effect of plant growth regulators on callus, cell suspension and cell line selection for flavonoid production from pegaga (Centella asiatica L. Urban). Am J Biochem Biotechnol. 2010;6(4):284-99. https://doi.org/10.3844/ ajbbsp.2010.284.299

22. Phua QY, Chin CK, Asri ZRM, Lam DYA, Subramaniam S, Chew BL. The callugenic effects of 2, 4-dichlorophenoxy acetic acid (2, 4-D) on leaf explants of Sabah snake grass (Clinacanthus nutans). Pak J Bot. 2016;48(2):561-66. Available from: http://www.pakbs.org/pjbot/ PDFs/48(2)/18.pdf

23. Smetanska I. Production of secondary metabolites using plant cell cultures. Adv Biochem. Engin./Biotechnol. 2008;111:187-228. https://doi.org/10.1007/10_2008_103

24. Hakkim FL, Kalyani S, Essa M, Girija S, Song H. Production of rosmarinic acid in Ocimum sanctum (L.) cell suspension cultures by the influence of growth regulators. Int J Biol Med. Res. 2011;2(4):115861. Available from: https://www.researchgate.net/ publication/277309487

25. Soontornchainaksaeng $P$, Chaicharoen $S$, Sirijuntarut M, Kruatrachue M. In vitro studies on the effect of light intensity on plant growth of Phaius tankervilliae (Banks ex L'Herit.) Bl. and Vanda coerulea Griff. Science Asia. 2001;27(4):233-37. https:// doi.org/10.2306/scienceasia1513-1874.2001.27.233 